\title{
Geoarchaeological evolution of Tel Akko's ancient harbour (Israel)
}

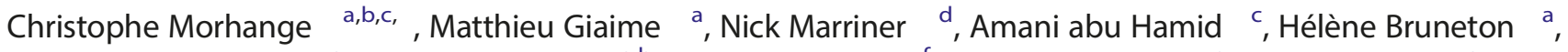 \\ Anasthasie Honnorat $\quad{ }^{a}$, David Kaniewski $\quad$ e,b , Frédéric Magnin $\quad{ }^{f}$, Alexeï V. Porotov $\quad{ }^{g}$, Jérôme Wante ${ }^{a}$, \\ Dov Zviely ${ }^{c, h}$, Michal Artzy ${ }^{c}$ \\ ${ }^{a}$ Aix-Marseille University, CEREGE, Europôle de l'Arbois BP80, F 13545 Aix-en-Provence, France \\ b IUF, 103 boulevard Saint Michel, F 13005 Paris, France \\ c University of Haifa, Hatter Laboratory, Leon Recanati Institute for Maritime Studies, Mount Carmel, Haifa 3190501, Israel \\ d CNRS, Laboratoire Chrono-environnement, UMR CNRS 6249, MSHE USR 3124, Univ. Bourgogne Franche-Comté, 25000 Besançon, France \\ e Université Paul Sabatier-Toulouse 3, EcoLab, IUF, Bâtiment 4R1, 118 Route de Narbonne, 31062, Toulouse cedex 9, France \\ ${ }^{f}$ CNRS, IMBE, Aix-Marseille University, Europôle de l'Arbois BP80, 13545 Aix-en-Provence, France \\ ${ }^{g}$ Lomonossov State University, Geographical Faculty, Moscow, Lininskie Gori, 119991 Moscow, Russia \\ h School for Marine Sciences, Ruppin Academic Center, Michmoret, Israel
}

\begin{abstract}
a b s tract
Archaeological excavations at Tel Akko, northern Israel, located some $1.5 \mathrm{~km}$ east of the present ancient city, have revealed imported artefacts and evidence for maritime $t$ rade dating from the early part of the 2nd millennium BC onwards ( Dothan, 1993 ). These findings strongly support the existence of a harbour (or anchorage) at the site, although its exact location and associated facilities have yet to be elucidated. Se dimentological and palaeontological analyses, together with ${ }^{14} \mathrm{C}$ dates of cores drilled around Tel Akko, provi de new palaeo-enviro nmental information to help to reconstruct shoreline change $s$ during the last ca. 4000 years. First, we propose that the southern facade of the tell constituted the harbour environment, characterised by marine environments until ca. 2800 years BP; the site was protected by a natural rocky breakwater and a sandbar which were silted-up and transformed into a freshwater marsh. This environment might have been used as an anchorage by the tell's inhabitants before the early1st millennium BC. Secondly, it seems that the eastern side of the tell was flanked by a sandy coast, that had prograded, offering an open anchorage until the Late Persian/Hellenistic period in the southwestern area of the tell. These results are being cross-chec ked by geophysical surveys, rescue archaeology and should be validated by further archaeological excavations.
\end{abstract}

\section{Introduction}

Beginning in the 1980 s, a series of geoarchaeological projects have focused on different ancient harbours and coastal sites of Israel, namely at Caesarea ( Raban and Hohlfelder, 1981; Nir and Eldar, 1987; Raban, 1992; Reinhardt and Raban, 1994; Reinhardt and Raban, 1999; Reinhardt et al., 1994,2006; Siv an et al., 2001,2004; Shtienberg et al., 2014 among many others), Dor ( Wachsmann and Raveh, 1984; Raban, 1987b; Kingsley and Raveh, 1996 ), the Atlit sites (Galili and Nir, 1993; Galili et al., 1993; Haggi and Artzy, 2007 the Phoenician basin), Haifa Bay ( Zviely et al., 2006, 2007, 2009; Porat et al., 2008 ), Akko ( Galili et al., 2010; Rosen et al., 2012 ) Nami (Artzy, 2006; Salmon 2014 ) and Magdala harbour on the banks of

\footnotetext{
$\triangle$ To the memory of Joseph Treidel (1876 -1929) in recognition of the exceptional maps he produced of the Akko area between 1925 and 1926.

$\otimes$ Corresponding author at: Aix-Marseille University, CEREGE, Europôle de I "Arbois BP80, F 13545 Aix-en-Provence, France.

E-mail address: morhange@cerege.fr (C. Morhange).
}

the Kinneret (Galilee) Sea ( Raban, 1988; De Luca, 2012; Lena, 2012; Sarti et al., 2013 ; Rossi et al., 2014; De Luca and Lena, 2014 ). Paradoxically, the evolution of the major harbour sites of Tel Akko has been neglected.

Tel Akko is one of the oldest coastal settlements of the Mediterranean world (2000-1750 years BC) ( Artzy, 2012 ; Fig. 1). It is situated near the Na'aman (Belos) River ( Zviely et al., 2006; Lichter et al., 2009 ). It has, therefore, been affected by important environmental changes at various temporal and spatial scales ( Artzy, 2012 ). Unresolved archaeological questions relate to the location of Akko's landlocked anchorages (Dothan and Raban, 1980 ). Inbar and Sivan (1984) and Zviely et al. (2006) investigated geological issues, especially in the northwestern area close to the tell. However, these studies did not elucidate the coastal changes in relation to the position of the ancient anchorages.

By reconstructing the coastal topography of the ancient city and its palaeo-environmental context since the Bronze Age, our results shed new light on the environmental evolution of the Tel Akko area. In addition, we have investigated the locations of ancient anchorages, which is a topic directly linked to the geomorphological 

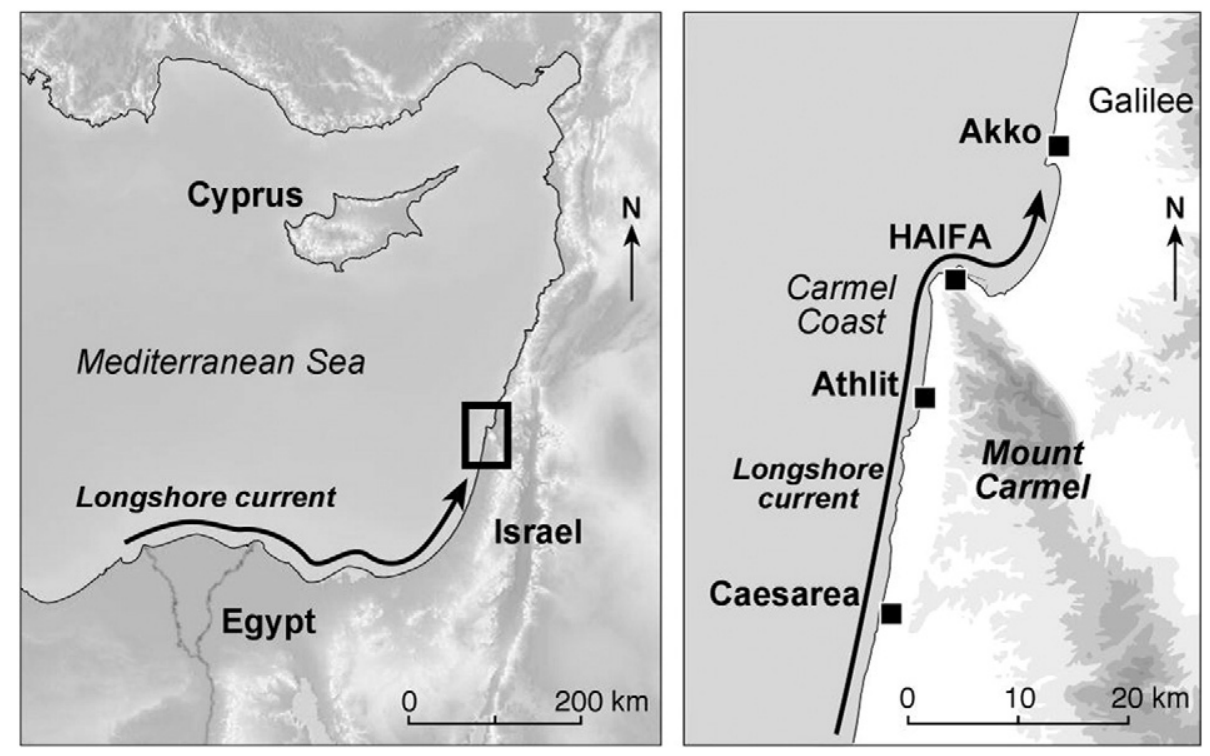

Fig. 1. Location map. Akko (Northern Israel) in the Eastern Mediterranean basin.

processes in action, e.g.: (1) relative sea-level changes; (2) regional shoreline fluctuations of Haifa Bay (Zviely et al., 2006, 2007, 2009); and (3) local environmental changes in the Na'aman estuary (Lichter et al., 2009, 2010, 2011).

Our aims are to answer the two following questions at a variety of temporal and spatial scales, including:

- to reconstruct shoreline changes and the evolution of anchorage potentialities (natural harbour, land-locking processes related to positive sedimentary budgets sensu Anthony et al., 2014). Where were the ancient harbours located from the Middle Bronze Age onwards?

- to elucidate the relationships between the settlement pattern and the coastal landscape, in parallel with the archaeological excavations carried out on the tell. What were the coastal environments of Tel Akko like during different periods, and when and how did these evolve (Marriner et al., 2014)?

\subsection{Geomorphological context and harbour location}

The ancient site of Tel Akko (Fig. 1) is located some $1.5 \mathrm{~km}$ east of the old city of Akko (Acre). Today's local inhabitants often refer to the mound as Tell el-Fukhar (the tell of the sherds) or "Napoleon's Hill", although both the tell and the modern site of Akko have undergone several name changes over the centuries (Artzy, 2015). During the Hellenistic period, the construction of an artificial harbour in what is today known as the 'Old City' renamed Ptolemais and, later, Saint Jean d'Acre, the capital of the Crusader Kingdom, led to a migration of the population from the tell to the western coastal area (Galili et al., 2007 and 2010; Artzy, 2012; Gambash, 2014). The tell is situated on a fertile agricultural coastal plain, with plentiful water supply from natural springs and rivers (Artzy and Beeri, 2010). The best-protected natural anchorages along the south-eastern Levant coast are found in this area (Raban, 1991). Furthermore, its advantageous position, at the intersection between maritime and terrestrial routes leading eastwards to the Jordan Valley and the State of Jordan, encouraged trade. Akko was an important Eastern Mediterranean harbour for nearly 4000 years, from the Middle Bronze IIa, at the beginning of the 2nd millennium BC, to the British mandate. The Na'aman River mouth is located in Haifa Bay, at the northern end of the Nile littoral cell of Israel's Mediterranean coast (Figs. 1 and 2; Zviely et al., 2007). Lichter et al. (2009) have documented the morphological changes around the river's mouth based on historical maps from the last 200 years as well as a series of aerial photographs taken since 1945 . The spatio-temporal evolution of the Na'aman River mouth has been characterised by rapid lateral modifications (Fig. 3). For example, the mouth migrated $1.5 \mathrm{~km}$, both north and south, along the coast during the last 200 years, more or less equally in either direction (Lichter et al., 2009). Recently, anthropogenic intervention and an increase in vegetation cover have restricted the migration of the channel.

Research relating to relative sea-level changes in Akko is abundant. These data show a stabilization during the last millennia (Sivan et al., 2001, 2004, 2010; Toker et al., 2012). During the last 7000 years the level has risen by about $7 \pm 1 \mathrm{~m}$ and remained below its present level until about 3000-2000 years BP. Neotectonic activity appears to be marginal during the Late Holocene in the area of Akko (Sivan et al., 1999).

\subsection{Historical and archaeological contexts}

The name Akko first appeared in the Ebla texts, dating to ca. $2400-2250$ years BC. It is one of the cities mentioned in the early second millennium Egyptian Execration Texts and appears in the Amarna texts, and again in the military texts of the Pharaohs of the 19th dynasty. It was also mentioned in the Ugaritic texts, the Bible and later in the Annals of the Assyrian kings, Sennacherib and Esarhaddon (Artzy and Beeri, 2010).

Excavations at Tel Akko, first headed by Dothan (1976), unearthed a rampart, reaching a height of $22 \mathrm{~m}$ and $60 \mathrm{~m}$ width, a fortress on the summit of the tell and a massive gate all dating to the early 2nd millennium BC. Imports from the Lebanese coast as well as from Cyprus underscore the importance of the anchorage and the trade network (Artzy and Beeri, 2010). During the first part of the 1st millennium $\mathrm{BC}$, the site experienced a reduction in population, whereas the habitation pattern increased after ca. 700600 years BC, the period in which Phoenicians, Persians and Greeks were present (Gambash, 2014). In 332 BC, Akko fell to Alexander the Great. Ptolemy II changed the city's name to Ptolemais. Remains dating to the Roman period have been found, mainly north of the Peninsula (Abu Hamid, 2012). Part of a Roman road, probably connecting the city with Damascus was noted (Finkielsztejn, 2007) as well as a large Roman cemetery on the northwestern foothill of the tell (Tepper, 2010). On Tel Akko itself no Roman period settlement was noted. The tell was abandoned in the first part of the 2nd century BC, 


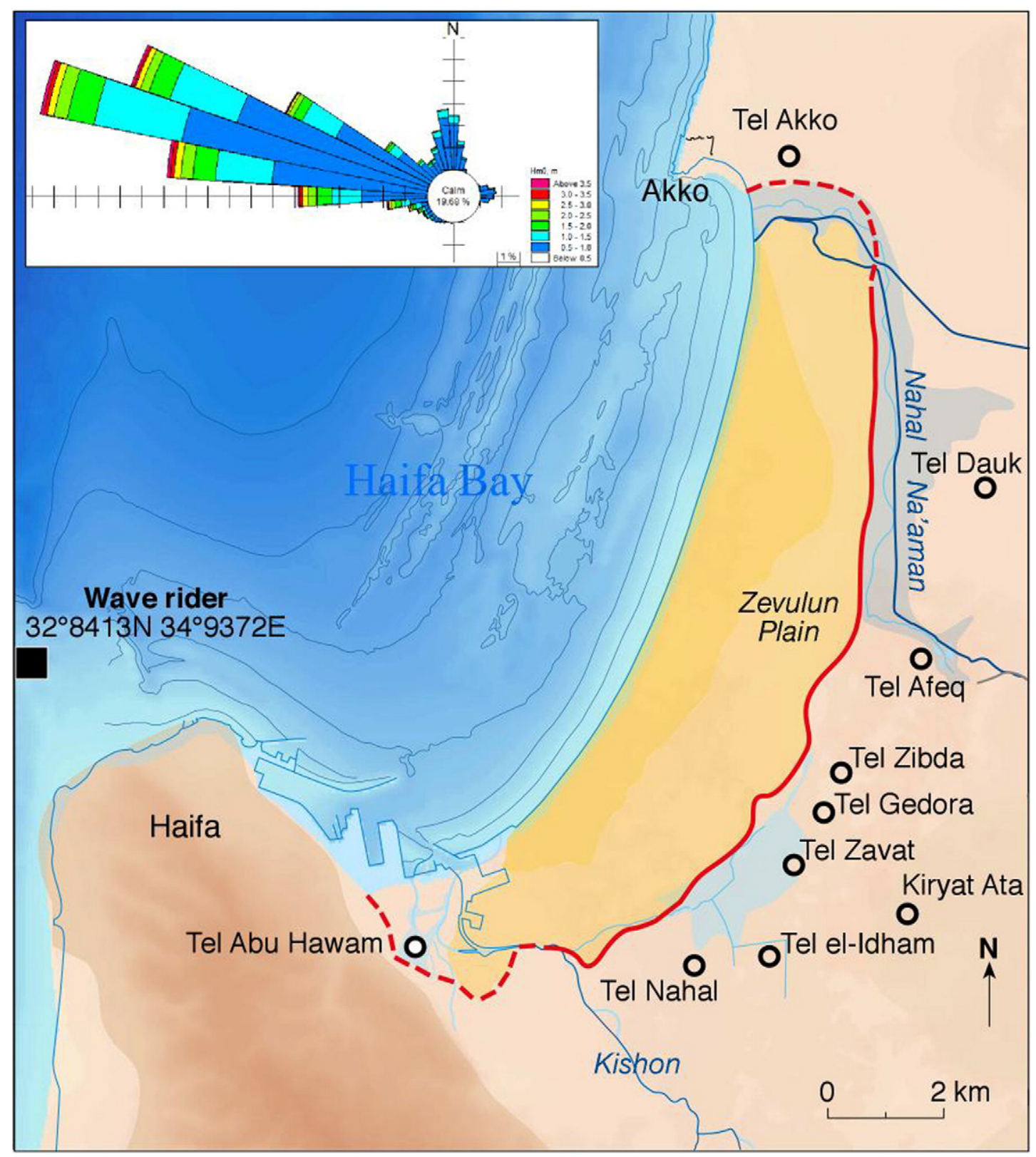

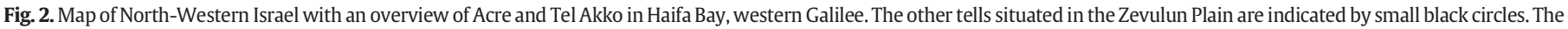
palaeocoastline, for the period 4000-3000 cal years BP (Zviely et al., 2007), is marked in red. Wave rose from CAMERI (Israeli Coastal and Marine engineering Institute).

although a tower was placed in its midst in the 13th century AD (Artzy, 2012, 2015). During the Arab conquest in the 7th century AD, the tell was definitively abandoned, and major activity moved to the "Old City" of Acre, in the vicinity of a man-made harbour (Galili et al., 2010).

\section{Methods}

Nine cores were taken from around Tel Akko (Fig. 4). Continuous cores were drilled on the southern and western footsteps of the tell. Cores were geodetically measured relative to the Israeli Transverse Mercator (ITM) new geographic coordinate system using a GPSRTK. The coring tube used in this study had a $20 \mathrm{~cm}$ diameter and could be extended by adding $1 \mathrm{~m}$ segments. Each core was described and sampled directly at the investigated site. Core stratigraphies were divided into units and described according to their texture, grain size, and macrofossil content. In the laboratory, we adopted the classic methodology detailed by Marriner and Morhange (2007) and Marriner (2009) to analyse the 5 cores (AK 2, 5 , 6,8 and 9). The sand fraction (between $50 \mu \mathrm{m}$ and $2 \mathrm{~mm}$ ) was sieved and examined under a binocular microscope. Grain size analyses of the sand fraction were undertaken based on Folk (1980). Macrofauna, ostracoda and foraminifera were picked and identified (Athersuch et al., 1989; Lachenal, 1989 for ostracods; Poppe and Goto, 1991, 1993; Doneddu and Trainito, 2005 for the macrofauna; Cimerman and Langer, 1991 for the foraminifera). Radiocarbon dating was performed at the Poznan Radiocarbon Dating Center. The chronology is based on accelerator mass spectrometry (AMS) radiocarbon $\left({ }^{14} \mathrm{C}\right)$ ages (Table 1$)$. All conventionally determined radiocarbon ages were calibrated using IntCal 13 and Marine13. For dated shells samples, we calculated a local marine reservoir age of 286 years (Weighted Mean $\Delta \mathrm{R}=3$; Standard 


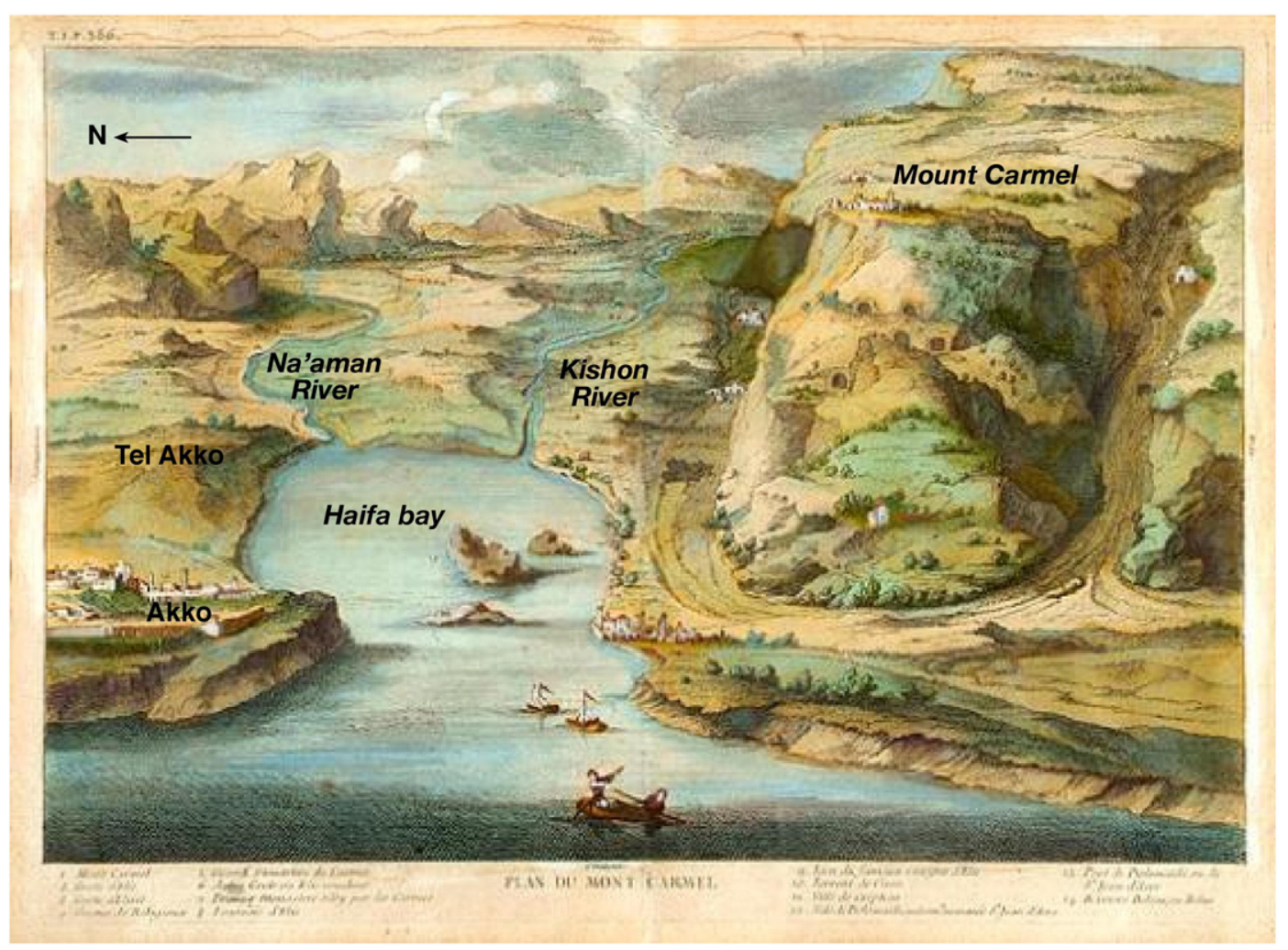

Fig. 3. Ancient engraving of Haifa Bay from Jean Doubdan (1667).

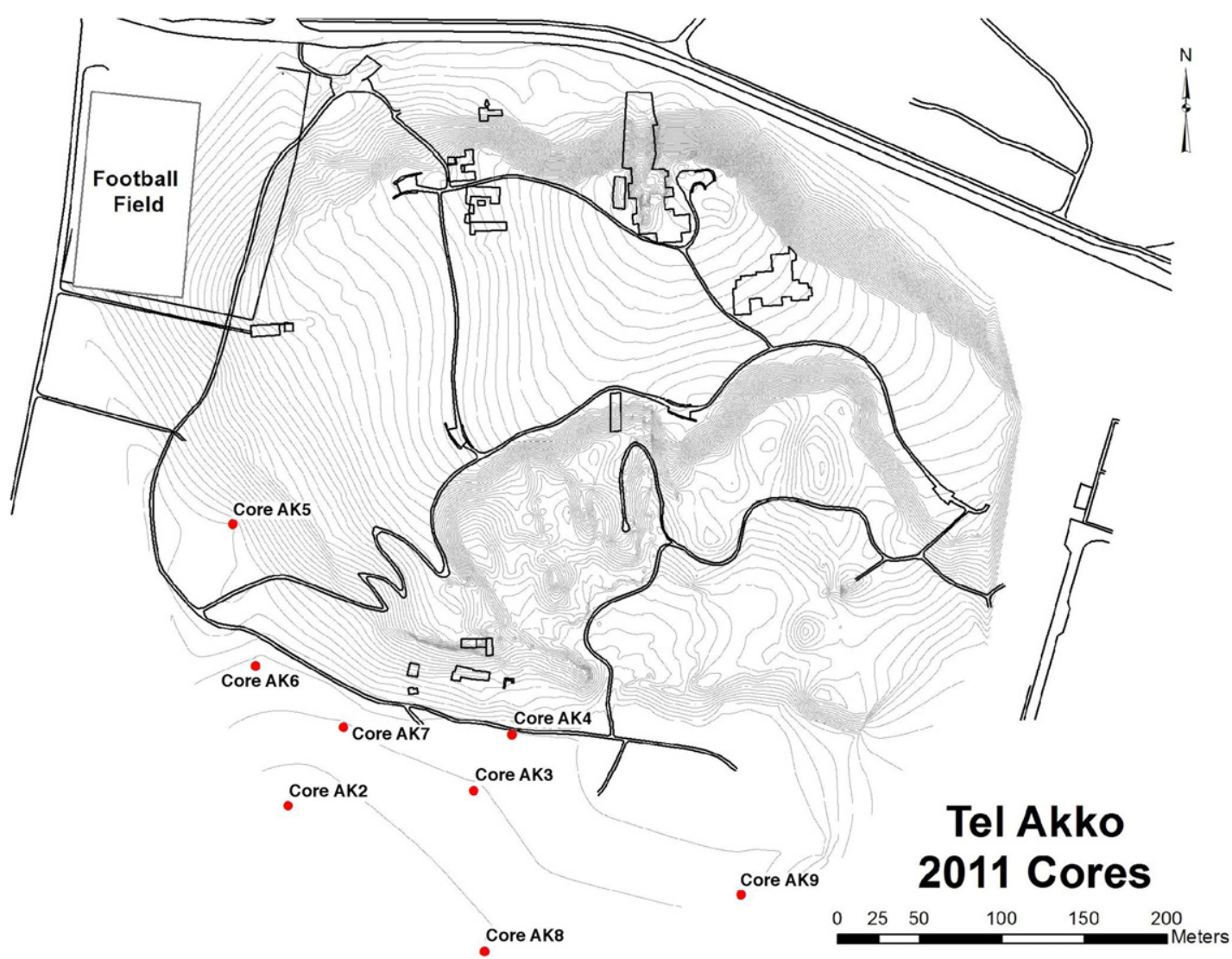

Fig. 4. Location of cores, Akko (mission 2011). 
Table 1

Radiocarbon determinations and calibrations.

\begin{tabular}{|c|c|c|c|c|c|}
\hline Core & Depth $(\mathrm{cm})$ & Material & Lab code & ${ }^{14} \mathrm{C}$ & Calibrated date \\
\hline Ak 2 & $72-83$ & Seeds & Poz-50071 & $120 \pm 30 \mathrm{BP}$ & cal AD 1679-1939 \\
\hline Ak 2 & 93-98 & Seeds & Poz-50072 & $130 \pm 30 \mathrm{BP}$ & cal AD 1675-1941 \\
\hline Ak 2 & $106-123$ & Seeds & Poz-50073 & $180 \pm 25 \mathrm{BP}$ & cal AD 1658-1950 \\
\hline Ak 2 & $168-203$ & Seeds & Poz-50075 & $1035 \pm 35 \mathrm{BP}$ & cal AD 897-1117 \\
\hline Ak 2 & 289-314 & Seeds & Poz-50076 & $1965 \pm 35 \mathrm{BP}$ & cal BC 43 - cal AD 121 \\
\hline Ak 5 & $460-620$ & Potsherd (Marmit) & & & ca. 2000 BC \\
\hline Ak 5 & $620-650$ & Glycimeris sp. & Poz-53644 & $4000 \pm 140 \mathrm{BP}$ & cal BC 2474-1639 \\
\hline Ak 8 & $325-360$ & Potsherd (Marmit) & & & ca $500 \mathrm{BC}$ \\
\hline Ak 8 & $320-328$ & Charcoal & Poz-53647 & $1975 \pm 30 \mathrm{BP}$ & cal BC $43-$ cal AD 79 \\
\hline Ak 8 & $352-360$ & Potsherd (storage jar) & & & 2nd millennium BC (MB or $\mathrm{LB}$ ) \\
\hline Ak 8 & $392-400$ & Raphitoma horrida & Poz-57478 & $2830 \pm 35 \mathrm{BP}$ & cal BC 787-401 \\
\hline Ak 8 & $408-416$ & Pirenella sp. & Poz-57477 & $5945 \pm 30 \mathrm{BP}$ & cal BC 4589-4249 \\
\hline AK 9 & $400-420$ & Grape seed & Poz-53643 & $2400 \pm 35 \mathrm{BP}$ & cal BC 742-397 \\
\hline AK 9 & $620-690$ & Wood & Poz-53645 & $2670 \pm 35 \mathrm{BP}$ & cal BC 896-798 \\
\hline
\end{tabular}

Deviation $=73$ ) using six published ages from Reimer and McCormac (2002) and Boaretto et al. (2010) (Table 2).

\subsection{Results from the southern facade of the tell (three cores: $A K 2,8$ and 9)}

Core AK 8 is located ca. $150 \mathrm{~m}$ from the southern limit of the tell, ca. $2.8 \mathrm{~m}$ above the present mean sea level. We were able to discriminate two main bio-facies (Fig. 5). We radiocarbon dated three samples from AK 8, spanning ca. 3000 years of environmental history along this southern facade.

Up until ca. 2800 years BP (facies A), the environment is characterised by a fine sandy sediment with a juxtaposition of coastal and fresh-water fauna. Nevertheless, about $25 \%$ of the texture is composed of silts attesting to a semi-open marine environment. The malacofauna is characterised by marine species, mainly Loripes lucinalis and Donax semistriatus. However, some freshwater shells were identified (Theodoxus jordani and Melanopsis buccinoidea) attesting to the proximity and influence of the Na'aman marine-dominated estuary (sensu Boyd et al., 2006). The ostracods confirm these interpretations with the dominance of a coastal population composed of Aurila spp. and Loxoconcha spp.

Between ca. 2800 years BP and ca. 2500 BP (ca. 500 BC), based on ceramics found in the core (broken cooking pot), an important modification of the environment occurred (facies B), characterised by an upward fining of the sedimentary texture, with the presence of black silt typical of a semi-closed lagoonal environment (ca. 80\% silt and clay). The bio-indicators are characterised by important freshwater inputs with numerous well-preserved shells like T. jordani, Bithynia phialentis and the ostracod Candona angulata. Low relative abundances of marine shells may reflect medium-energy impacts (eg. Nassarius costulata, D. semistriatus) but the general texture remains silty. Cyprideis torosa, associated with the freshwater ostracods $C$. angulata and Ilyocypris gibba, are consistent with a polyhaline fluvial-dominated estuary (sensu Boyd et al., 2006). Since the Late Persian period, the environment therefore appears to be a well-protected stretch of water characterised by a very shallow water column, $<1 \mathrm{~m}$ in depth, and prone to progressive silting. The top of the core corresponds to an artificial infill dating to the British mandates of the 1940s to contain the Na'aman's swamps (Artzy and Quatermaine, 2014).

Core AK 9 reconstructs the chronology of the shift from an upper infratidal marine zone (facies A) to a fluvial-dominated estuary (facies B; Fig. 6). As was the case for core AK 8, facies A corresponds to an infratidal marine deposit characterised by ca. $75 \%$ of fine sands with the presence of marine shells, mainly Ovatella myositis and Melanatria omata. In the upper part of the unit, the proximity of sea level is marked by the mixing of freshwater (Melanopsis tuberculata, Valvata saulcyi) and continental species (Myosotella denticulata), consistent with terrestrial inputs and a natural silting of the depression. With the exception of the high faunal densities of the ubiquist $C$. torosa, the ostracods are of coastal origin (e.g. Aurila convexa, Pontocythere oblonga).

Facies B, dated after ca. $2400 \mathrm{BP}$, is located above present mean sea level. It corresponds to a sandy-silt environment, better protected than facies A. Few shells are attributed to fluvial environments (M. buccinoidea, Bithyniidae sp.) very similar to facies B of core AK 8 . The shift from an infratidal marine-dominated estuary to a fluvialdominated estuary is almost synchronous in cores AK 8 and AK 9 and can be attributed to the Iron Age. Before this period, the environment corresponds to the upper part of a semi-open marine environment that may have been used as a natural anchorage until the Late Persian-Early Hellenistic period (ca. $300 \mathrm{BC}$ ). After this period, silting transformed the water body into a marshy environment, with a very restricted water column not particularly conducive to hosting maritime vessels and harbour activities.

On the south-western part of Tel Akko, we drilled core AK 2. We radiocarbon dated five samples to constrain the 2000 years of environmental evolution of the harbour's southern facade (Fig. 7). Unit A, at the base of the core, is characterised by a peat layer. The ostracofauna is typical of an open lagoon environment with a high relative abundance of $C$. torosa and lower abundances of Xestoleberis sp., Pontocythere sp. and Neocytherideis cylindrical (Lachenal, 1989). The top of the unit is dated to ca. 2000 years BP. After this date, the site is characterised by

Table 2

Published reservoir age dates used to calculate the local reservoir age at Akko.

\begin{tabular}{|c|c|c|c|c|c|c|c|c|c|c|}
\hline Lon & Lat & DeltaR & DeltaR Err & Reference & Locality & Collection Year & Reservoir Age & Reservoir Err & C14age & C14err \\
\hline 35.0138 & 32.8431 & -115 & 50 & Boaretto et al. (2010) & Israel & 1937 & 174 & 54 & 345 & 50 \\
\hline 34.9227 & 32.6432 & -20 & 50 & Boaretto et al. (2010) & Israel & 1937 & 269 & 54 & 440 & 50 \\
\hline 34.9227 & 32.6432 & 75 & 50 & Boaretto et al. (2010) & Israel & 1937 & 364 & 54 & 535 & 50 \\
\hline 34.8482 & 32.3384 & 47 & 40 & Boaretto et al. (2010) & Israel & 1937 & 342 & & 510 & 40 \\
\hline 34.8482 & 32.3384 & -70 & 50 & Boaretto et al. (2010) & Israel & 1937 & 219 & 54 & 390 & 50 \\
\hline 34.83 & 32.17 & 52 & 40 & Reimer and McCormac (2002) & Netamiya, Israel & 1937 & 349 & 41 & 510 & 40 \\
\hline
\end{tabular}




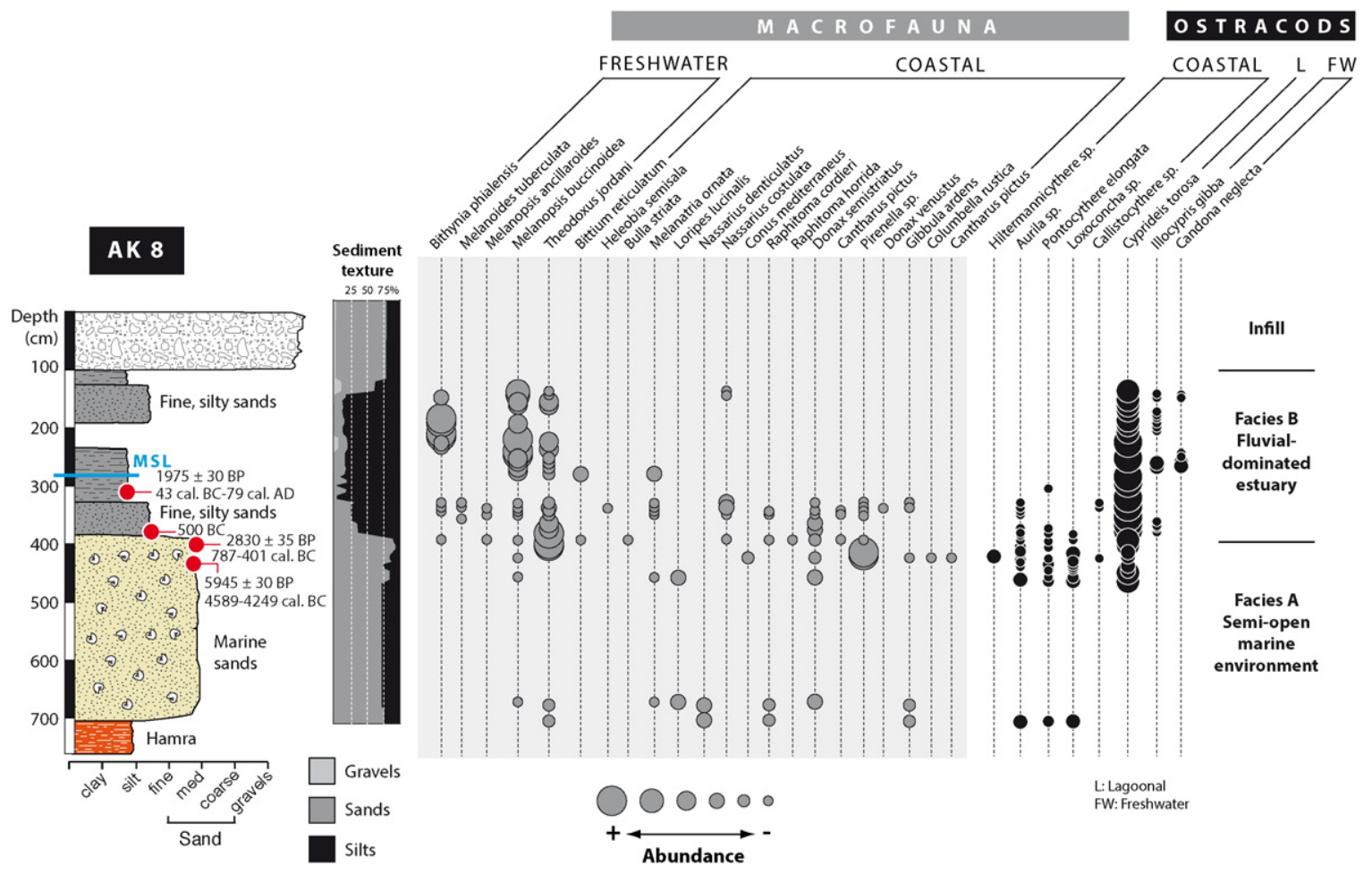

Fig. 5. Biosedimentology of core AK 8 .

the same land-locking processes, with a progressive closure of the environment, which is consistent with the presence of a restricted lagoon environment corresponding to a fluvial-dominated estuary. A monospecific ostracofauna comprising $C$. torosa is typical of a restricted water body. The macrofauna attests to the influence of freshwater inputs with T. jordani, Heleobia semisalsa contempta, Bithynia phalensis, Bithyniidae, M. buccinoidea and Melanoides tuberculatus. The sedimentary matrix is mainly composed of silty-sands, indicating a relatively calm environment (unit B2). Unit B1, since ca. 1000 years BP, translates the closure of the environment. It is mainly composed of silts and fine sands, representative of a low-energy environment. The majority of the ostracods are attributed to the polyhaline-lagoonal assemblage (C. torosa). Macrofauna show a relative drop in freshwater species (H. semisalsa contempta, Bithyniidae, M. buccinoidea and M. tuberculatus) and the appearance of terrestrial species (M. denticulata, Monacha sp., Hygromiidae). The final phase of the silting-up occurred very recently,

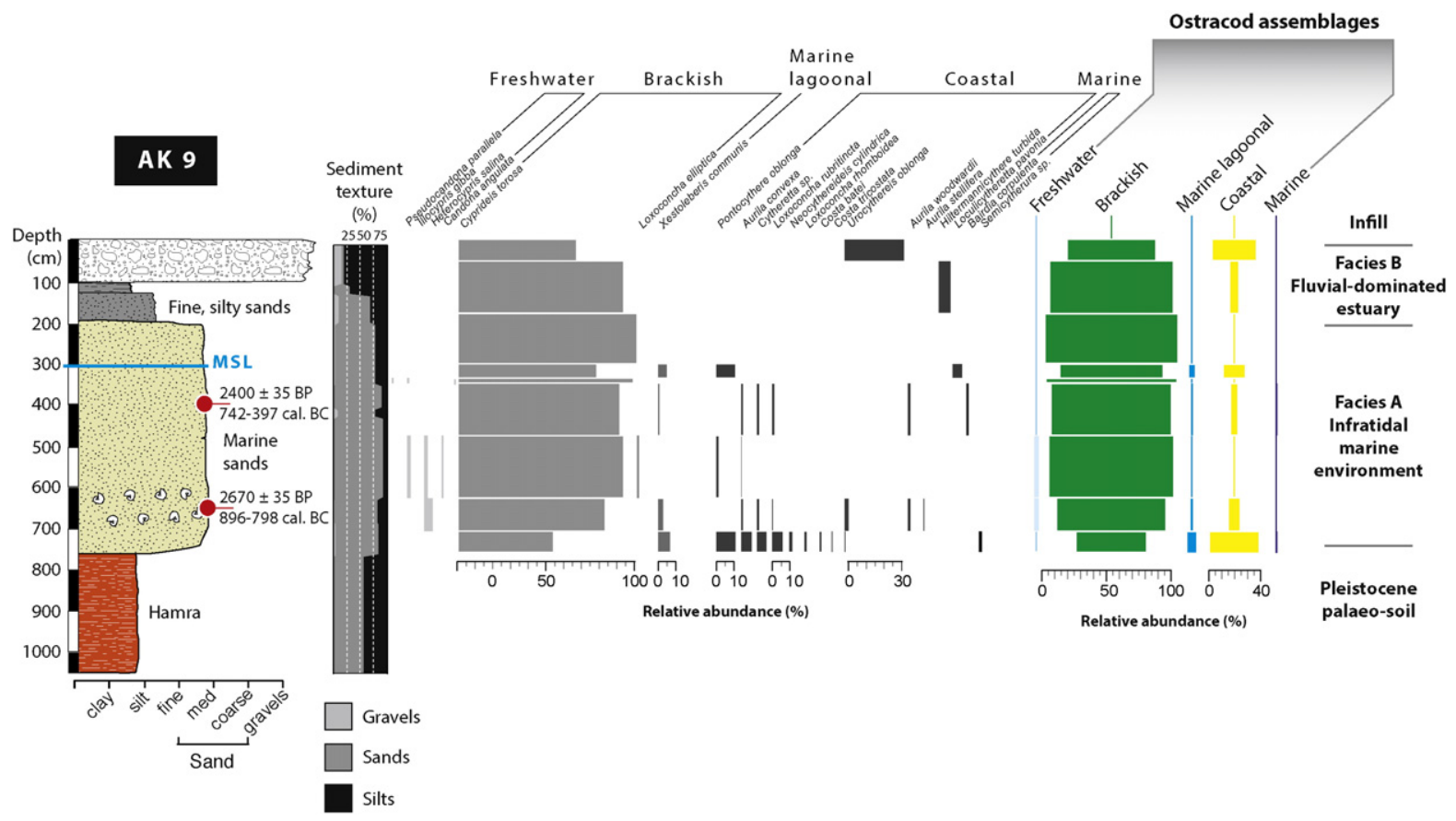

Fig. 6. Biosedimentology of core AK 9 . 


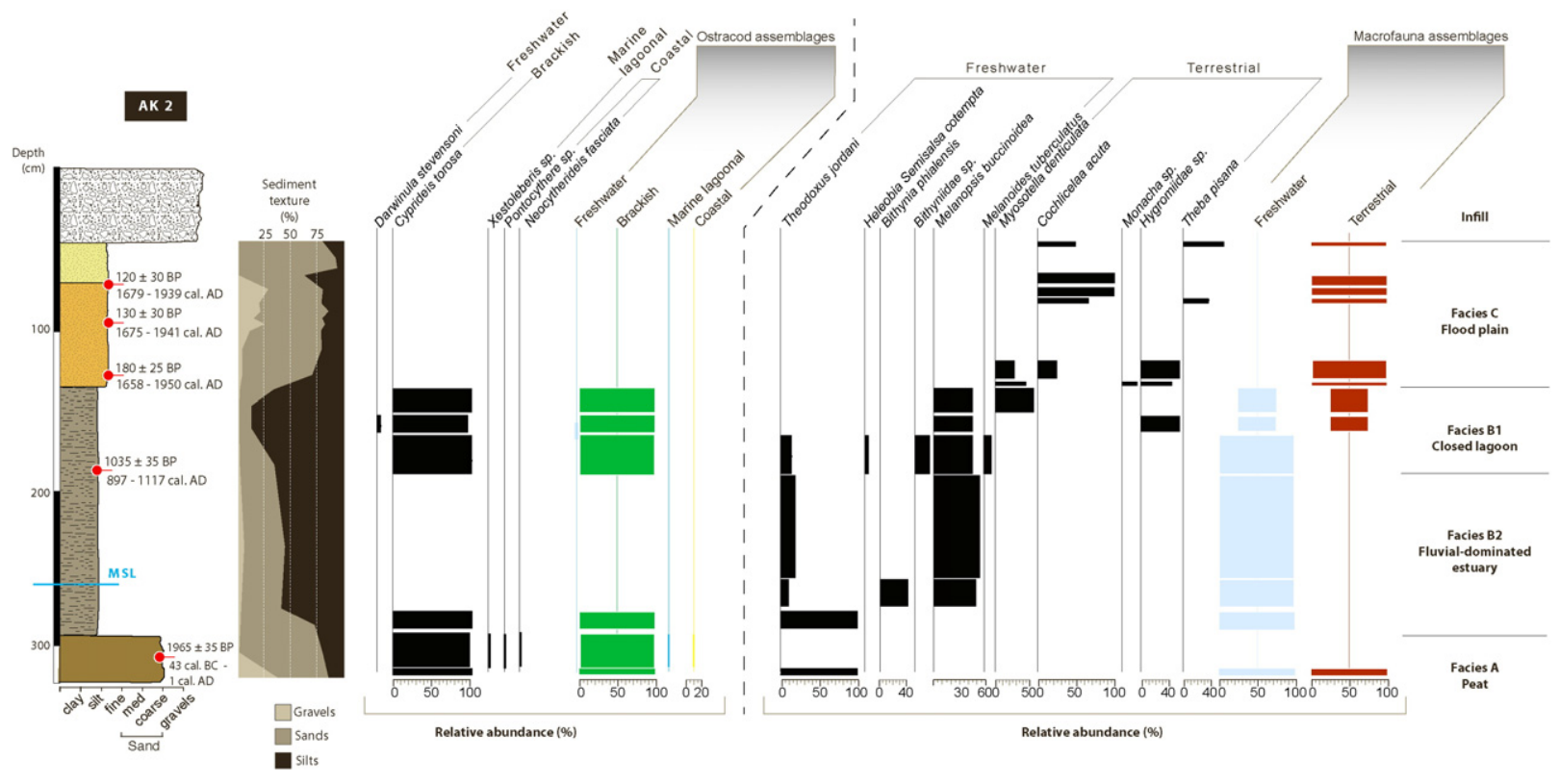

Fig. 7. Biosedimentology of core AK 2.

around 200 years BP. Unit C is characterised by the presence of continental macrofauna ( $M$ denticulata, Cochlicella acuta, Monacha, Hygromiidae, Theba pisana). Compared with cores 9 and 8, the closure of the environment happened later, around 2000 years BP, maybe linked to the remoteness of the marginal swamp in relation to the palaeoNa'aman's riverbed, which lay closer to core 8.

\subsection{Results from the Western facade of the tell (cores $A K 5$ and $A K 6$ )}

In order to interpret the progressive closure of the southern lagoon between 2800 years BP and 2000 years BP, we analysed two cores.

\subsection{Core AK 5 (Fig. 8)}

Unit A is composed of ca. $80 \%$ of sands, with an important fraction of medium and coarse sand, identical to the present-day sandy facies of Haifa Bay around Akko. We found few reworked marine species, from the upper part of the infratidal zone (Glycimeris sp., Bittium sp., Tellina sp., Hexaplex trunculus). The ostracoda are consistent with a coastal environment, including species such as $A$. convexa, P. oblonga, Hiltermannicythere sp. and Urocythereis oblonga. Unit A is typical of a sandy beach in an open bay, close to sea-level ca. 4000 years BP.

\section{AK 5}

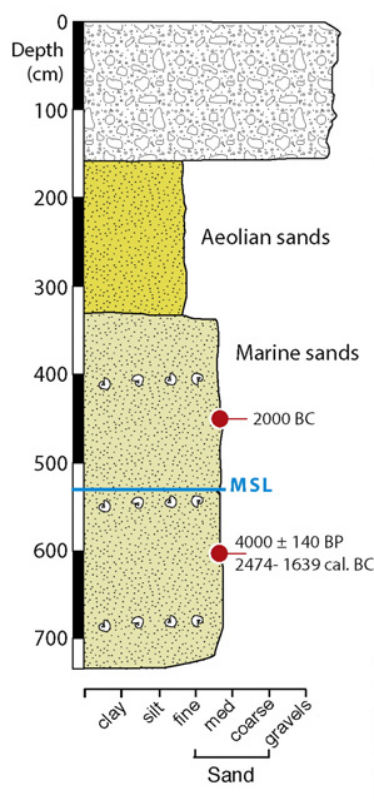

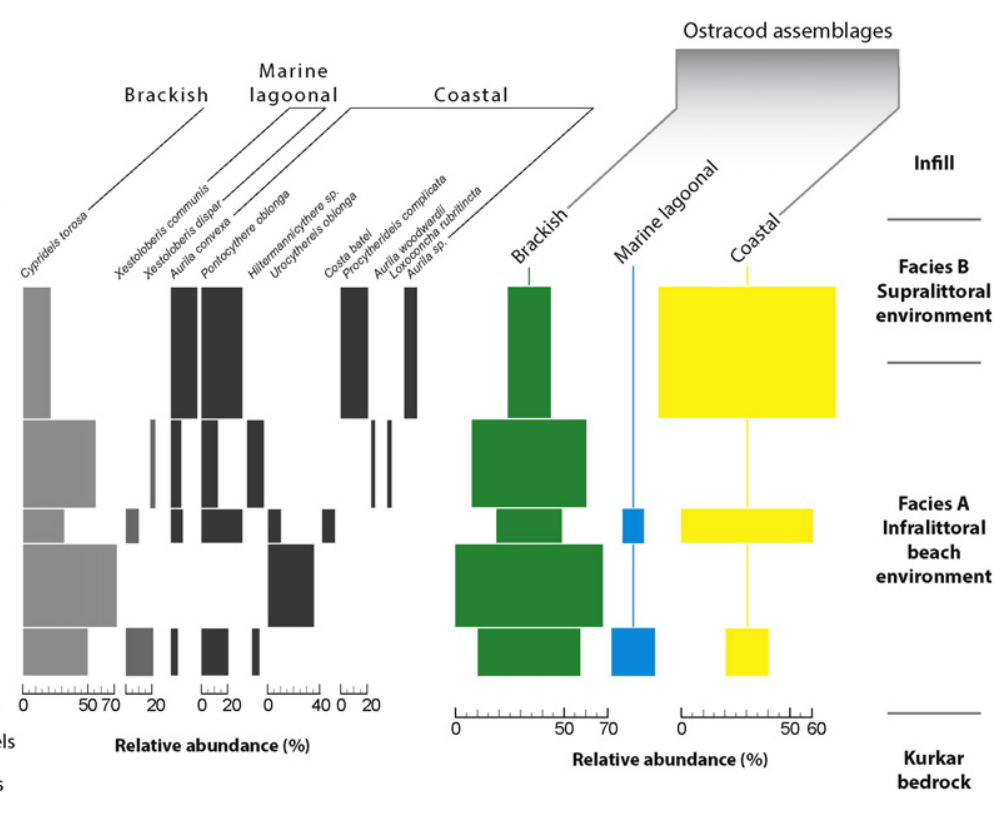

Fig. 8. Biosedimentology of core AK 5. 


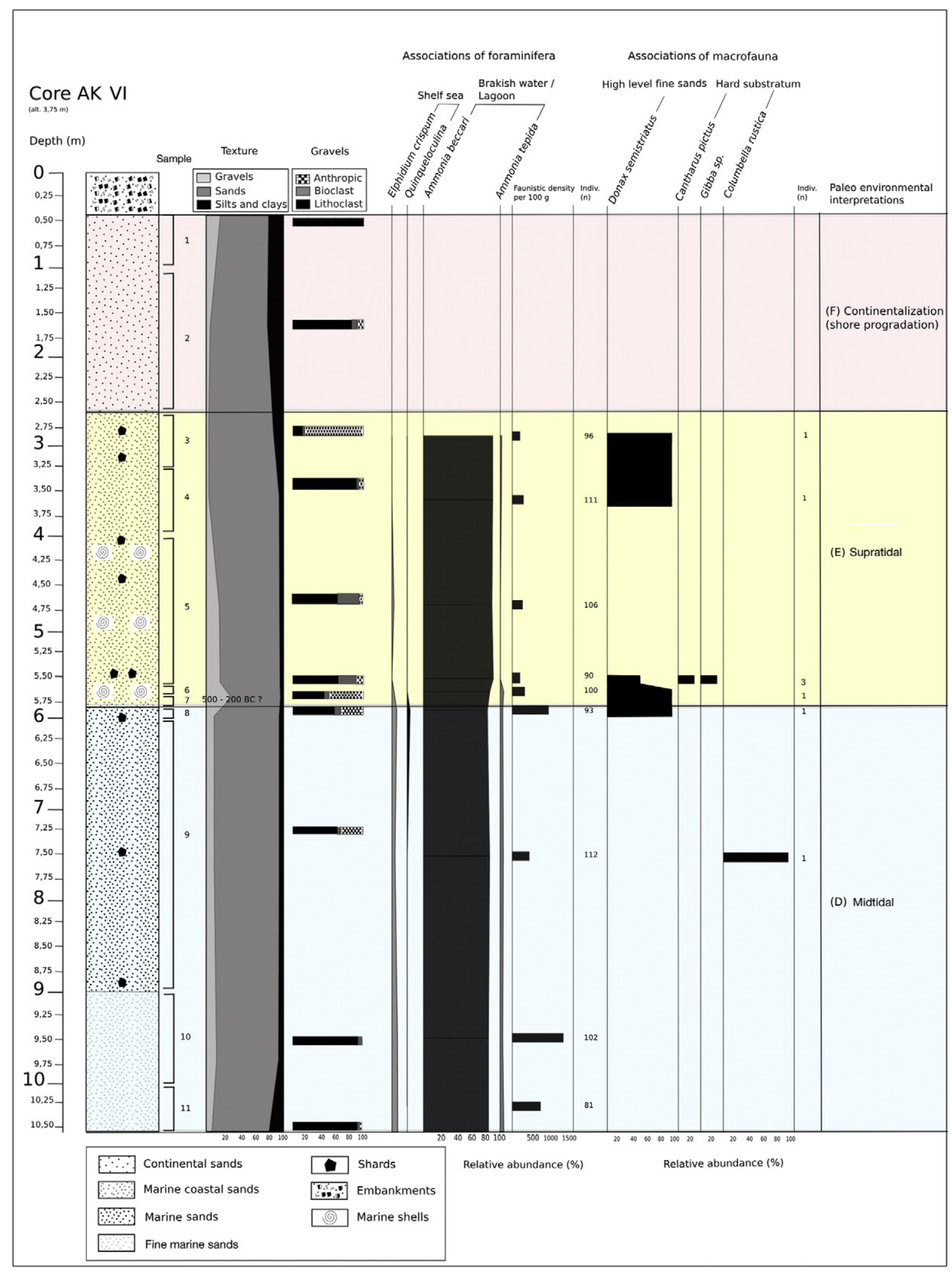

Fig. 9. Biosedimentology of core AK 6 (from Wante, 2012).

The top of unit A is coarser with $30 \%$ of the texture composed of litoclasts and reworked bioclasts. It may mark the mid-tidal zone at the base of the tell. Above, we found sandy beach facies, composed of $80 \%$ fine sands, typical of reworked aeolian quartz. These sedimentary facies show an open environment characteristic of a prograding spitlike coast. The nearby core AK 6 presents the same evolution (Fig. 9).

A recent Israel Archaeology Authority salvage project took place on the south-western part of the tell. The results of the excavations were 
Until 2800 years BP

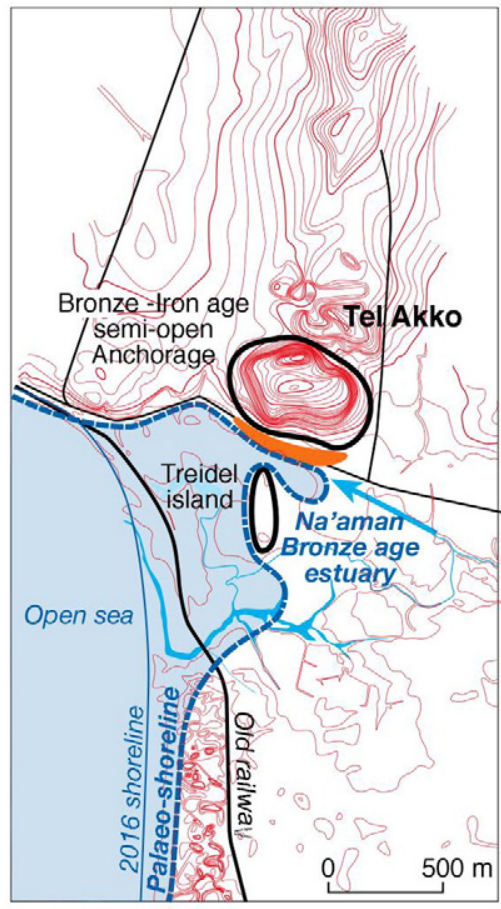

2800-2000 years BP

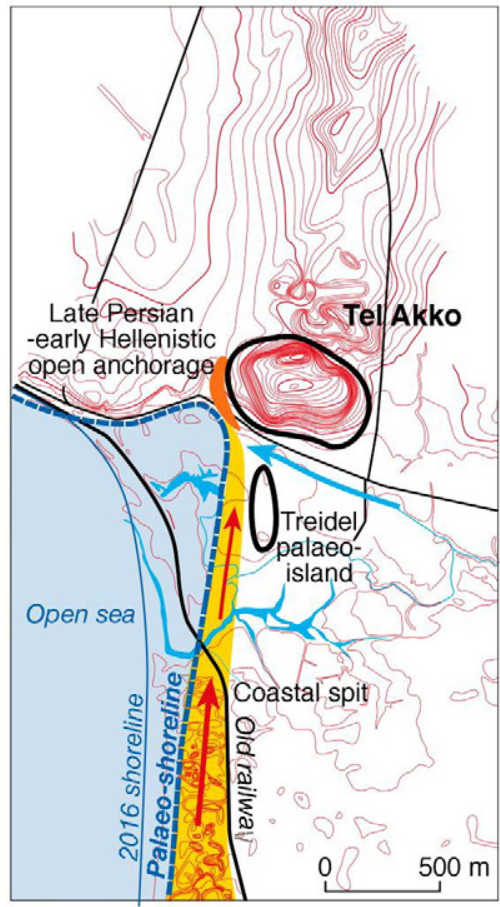

2016 AD

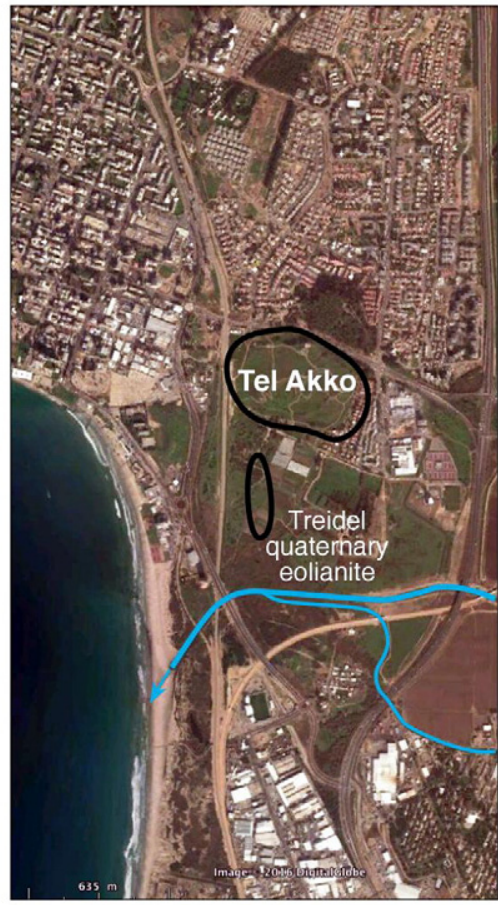

Fig. 10. Palaeogeographic reconstruction until 3000 years BP. Topography adapted from Treidel map (1925-26).

very interesting. On the slope itself, small industrial areas dating to ca. the 4th century BC were found. Late Persian to early Hellenistic remains were also founded. Sand facies bearing shells and ceramics were discovered and delineate a high-energy coastline (Artzy, 2012).

\subsection{Possible interpretations: natural coastal changes and ancient harbour locations}

The coastal evolution comprises two main phases (Fig. 10).

\subsubsection{From a semi-open marine environment (marine-dominated estuary) to a choked lagoon (fluvial-dominated estuary) on the southern edge of Tel Akko}

The semi-open marine environment on the southern edge of Tel Akko was a suitable natural anchorage until ca. 2800 years BP, broadly speaking since the Late Persian period. Therefore, from an environmental perspective, the southern border of Tel Akko during the Bronze Age comprised a shoreline close to the Na'aman palaeo-estuary (Kaniewski et al., 2013, 2014). Raban (1987a) correctly asserted that Tel Akko is located on the northern edge of the $\mathrm{Na}^{\prime}$ aman estuary and that $\mathrm{ca}$. 2000 years BC, the estuaries of ancient Israel underwent a process of rapid silting, eventually hindering harbour activities.

After ca. 2800 years BP, restricted connections with the marine environment made the anchorage less attractive. To keep abreast with the advancing shoreline, the harbour sites were relocated. Abu Hamid and Artzy excavated a Persian settlement on the western border of the tell and interpreted this location as evidence of harbour activities, in connection with the proximity of a marine beach possibly used as an open harbour during the pre-Hellenistic period.

In Haifa Bay and the Zevulun Plain dominant morphological processes were mainly controlled by relative sea-level rise from the Early Holocene up to about 4000 years ago, (Zviely et al., 2006,2007). During this period the invading sea flooded the region: the Zevulun Plain became a marine bay. From about 3650 years ago, when sea level reached its present elevation, the marine bay was mainly affected by sand infill, and the coastline migrated westwards. Porat et al. (2008) estimated that from ca. $4000 \mathrm{BP}$ and until $3650 \mathrm{BP}$, the coastline started to migrate seaward at an average rate of $\sim 40 \mathrm{~cm} /$ year. Subsequently, from the location of Qiryat Yam, about $1.7 \mathrm{~km}$ from the present coastline, the coastline continued to migrate westwards at $\sim 50 \mathrm{~cm} /$ year up to the present.

\subsubsection{Progradation of the Late Holocene coastal sandbars system}

Following the maximum marine ingression about ca. 4000 years ago, alluvial sediments progressively covered the Zevulun plain, and the coastline moved westward to its current position (Zviely et al., 2006). Bronze Age tells on the Zevulun plain are all located to the east of the current shoreline and are anterior to 3000 years BP, evidence of the westward migration of the shoreline (Inbar and Sivan, 1983; Artzy, 2006; Porat et al., 2008). For the last 3000 years, there are no archaeological finds from the northern Zevulun plain indicating the gradual westward migration of the coastal plain to its present location, except around Tel Akko. Alluvial sediments were transported from the southeast by the Na'aman river. Flood events occasionally transported sediments to the plain, in a similar vein to present-day flood episodes (Vachtman et al., 2012).

The Nile littoral cell is one of the Mediterranean's longest. It runs $650 \mathrm{~km}$ from Abu Quir Bay near Alexandria, Egypt, to Haifa Bay on the northern Israeli coast (Inman and Jenkins, 1984). Haifa Bay constitutes the northernmost and final depositional sink of Nile-derived quartz sand, transported from the Nile Delta by longshore currents generated by approaching breaking waves. The net sand transport along the Mediterranean coast of Israel results from larger waves approaching from the west-south-west and the south-west compared to their counterparts from the west-north-west and the north-west.

Under typical weather conditions, the Carmel headland, to the south of Haifa Bay, provides a natural barrier that prevents sand from entering northward into the bay. Only high, south-west breaking waves $(\mathrm{Hs}>3.5 \mathrm{~m}$ ) can produce the strong northerly currents needed to overcome the headland barriers and move sand eastward into the bay. The current estimate for the annual average quantity of sand transported to Haifa Bay is about $80,000-90,000 \mathrm{~m}^{3}$. Prior to the construction of Haifa port - and its main breakwater - by the British 
(1929 to 1932), sand that was able to penetrate the Carmel headland barrier flowed freely along the bay's coast.

\subsection{Comparison with two other Levantine coastal tells: Tel Abu Hawam and} Gaza

Approximately $15 \mathrm{~km}$ south of Tel Akko, Tel Abu Hawam was extensively excavated in the 1930s and 1980s. Later excavations and surveys have been conducted at the site to investigate its environmental evolution. The strategic and sheltered position of the ancient port of Tell Abu Hawam is protected by the eastern flank of Mount Carmel at the mouth of the Qishon river. The site is presently situated ca. $1.5 \mathrm{~km}$ west of the present coastline, due in part to sediment transport from the Qishon river, sand from the Mediterranean and human intervention. The site, which is roughly at an equal distance from Cyprus and Egypt, was probably a 'port of trade' that served merchant interests especially of the northern areas, namely the Syrian-Lebanese coast, Anatolia, the Greek islands and Cyprus (Artzy, 2006). Nevertheless, the tell is a good example of environmental problems linked to its location at the mouth of the Qishon river and wadi Selman (palaeo-mouth of the Qishon river), near the active fault of Mount Carmel (Avnimelech, 1959). This artificial Egyptian-Canaanite "island" reflects the early capacity of human societies to reshape the coastal landscape more than three millennia ago (Balensi, 2000).

By contrast, the ancient harbours of Gaza are poorly known due to the geopolitical situation (Morhange et al., 2005). Base-level fluvial inputs have led to a progressive regularisation of the coastline (Sandler and Herut, 2000). In effect, Gaza's coastline occupies a more proximal position relative to the Nile delta, at ca. $150 \mathrm{~km}$ to the east of the Damietta branch of the Nile (Egypt). Around 6000 years ago, the coastal landscape was characterised by a system of estuaries. Like at Akko, the coastline during this period was more indented, with the foundation of important maritime settlements during the Bronze Age. The navigable estuary of wadi Ghazzeh must have served as a natural harbour. The longshore drift, which transports a sandy sediment load, partially explains the regularisation of the coastline and the infilling of the estuaries, confined by coastal bars and bordering dunes (Stanley, 2002). This coastal metamorphosis explains the formation, over several thousand years, of a long, quasi-continuous arched beach between the Nile delta and Gaza. The beach is limited by the presence of fossilized dunes of Late Pleistocene age, which are often capped by active dune systems and occasionally incised by wadis. In this context, the migration of ancient harbours in the palaeo-estuaries can be explained by landlocking. Like in Akko, it is a function of the infilling of the outlets by important fluvial, aeolian and marine sediment inputs (Morhange and Marriner, 2011).

\section{Conclusion}

As Artzy and Beeri (2010) demonstrated, excavations at Tel Akko have unearthed imported artefacts and evidence of maritime trade from the Middle Bronze Age (2200-1500 BC) onwards (Dothan, 1993). These findings indicate that the site must have had a harbour, but neither the type of harbour facilities nor their exact locations are known. Our research demonstrates that the southern shoreline of Tel Akko was suitable for maritime anchorages and harbours during the Bronze Age until the Archaic period, and that the western waterfront of the tell possibly corresponds to an open harbour during the Persian period. Natural potentialities and palaeo-hazards, mainly sedimentary budget at base level, explain the coastal changes and the successive relocations of Tel Akko's harbour from the Bronze Age southern marine bay to the western open harbour at the base of the tell during the Persian period and the foundation, during Hellenistic times, of the harbours of the old city of Acre. Our bio-sedimentological results should be cross-validated by future archaeological excavations in order to accurately locate the ancient harbour structures. Nevertheless, our data attest to a classic geomorphological evolution, characterised by a maximum marine ingression ca. 4000 years BP, rapidly counteracted by fluvial inputs at the origin of coastal progradation, as was the case at many coastal sites around the Mediterranean (Brueckner, 2005; Anthony et al., 2014).

\section{Conflict of Interest}

The authors have not disclosed any potential conflicts of interest.

\section{Acknowledgements}

This work has been carried out with the assistance of the Labex OT-Med (ANR-11-LABEX-0061) and of the A*MIDEX project ( $n^{\circ}$ ANR11-IDEX-0001-02), funded by the Investissements d'Avenir project funded by the French Government, managed by the French National Research Agency (ANR). Support was also provided by the Institut Universitaire de France, CLIMSORIENT and MISTRALS (Mediterranean Integrated Studies at Regional and Local Scales)-Paleomex-EnvimedGEOISRAEL, and by the Hatter Laboratory, Recanati Institute for Maritime Studies, University of Haifa. We thank all the field technicians and laboratory team members who have worked so diligently over the years to help us acquire the archaeological data. The authors warmly thank the anonymous reviewers and A. Fontana for careful revision of the manuscript.

\section{References}

Abu Hamid, A., 2012. Akko, the Post Office, Hadashot Arkheologiyot-Excavations and Surveys in Israel. pp. 1-124.

Anthony, E.J., Marriner, N., Morhange, C., 2014. Human influence and the changing geomorphology of Mediterranean deltas and coasts over the last 6000 years: from progradation to destruction phase? Earth-Sci. Rev. 139, 336-361.

Artzy, M., 2006. The Carmel coast during the second part of the Late Bronze Age: a center for eastern Mediterranean transshipping. Bull. Am. Sch. Orient. Res. 343, 45-64.

Artzy, M., 2012. Return to Tel Akko, its anchorages, harbour, and surroundings. Recanati Institute For Maritime Studies Newsletter, University of Haifa Vol. 37, pp. 5-14.

Artzy, M., 2015. What is in a name? 'Akko - Ptolemais - 'Akka - Acre. Complutum 26 (1), 205-212.

Artzy, M., Beeri, R., 2010. Tel Akko. In: Killebrew, A.E., Raz-Romeo, V. (Eds.), One thousand Nights and Days - Akko through the Ages. Hecht Museum, Haifa, pp. 14-23.

Artzy, M., Quatermaine, J., 2014. How and when did Tel Akko get its unusual banana

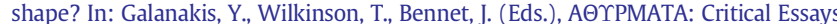
on the Archaeology of the Eastern Mediterranean in Honour of E. Susan Sherratt, pp. $11-22$

Athersuch, J., Horne, D.-J., Whittaker, J.-E., 1989. Marine and brackish water ostracods (superfamilies Cypridacea and Cytheracea): keys and notes for the identification of the species. Brill 1-366.

Avnimelech, M., 1959. Remarks on the geological features of the surroundings of Tell Abu Hawam and the cemetery in the area of the Qishon mouth. Atiqot 2, 103-105.

Balensi, J., 2000. Une île artificielle égypto-cananéenne (Haïfa, Israël). Le Monde de la Bible 128, 62.

Boaretto, E., Mienis, H.K., Sivan, D., 2010. Reservoir age based on pre-bomb shells from the intertidal zone along the coast of Israel. Nucl. Inst. Methods Phys. Res. 268, 966-968.

Boyd, R., Dalrymple, R.W., Zaitlin, B.A., 2006. In: Posamentier, H.W., Walker, R.G. (Eds.), Estuarine and Incised-Valley Facies Models Vol. 84. SEPM Special Publication, pp. 171-235.

Brueckner, H., 2005. Holocene delta progradation in the eastern Mediterranean-case studies in their historical context. Méditerranée 104, 95-106.

Cimerman, F., Langer, M.R., 1991. Mediterranean Foraminifera. Academia Scientarium et Aritium Slovenica, Dela, Opera 30, Classis IV: Historia Naturalis (118 pp., 93 pl.).

De Luca, S., 2012. Scoperte archeologiche recenti attorno al Lago di Galilea: contributo alla studio dell'ambiente del Nuovo Testamento e del Gesù storico. In: Paximadi, G. Fidanzio, M. (Eds.), Terra Sancta: archeologia ed esegesi. Atti dei convegni 2008-2010, ISCAB Serie Archeologica 1, Lugano, pp. 1-58.

De Luca, S., Lena, A., 2014. The harbor of the city of Magdala/Taricheae on the shores of the Sea of Galilee, from the Hellenistic to the Byzantine Times. In: Ladstätter, S. Pirson, F., Schmidts, Th. (Eds.), New Discoveries and Preliminary Results. Harbors and Harbor Cities in the Eastern Mediterranean from Antiquity to the Byzantine Period: Recent Discoveries and Current Approaches, Byzas 19, 1 (Istanbul), pp. 113-163.

Doneddu, M., Trainito, E., 2005. Conchiglie del Mediterraneo. Guida ai molluschi conchigliati. Il castello, Cornaredo, pp. 1-272.

Dothan, M., 1976. Akko: interim excavation report First Season 1973/74. Bull. Am. Sch. Orient. Res. 224, 1-48.

Dothan, M., 1993. Tel Acco, in: The new Encyclopedia of Archaeological excavations in the Holy Land, E. Stern ed. Jerusalem and New-York, pp. 17-24.

Dothan, M., Raban, A., 1980. The sea gate of ancient Akko. Biblic. Archaeol. 43, 35-40.

Doubdan, J., 1667. In: Clousier, G. (Ed.), Le voyage de la Terre Sainte, Paris. 
Finkielsztejn, G., 2007. Akko, Remez Street, Hadashot Arkheologiyot-Excavations and Surveys in Israel. pp. 1-112.

Folk, R.L., 1980. Petrology of Sedimentary Rock. Hemphill Publishing Company, Austin, Texas, pp. 1-184.

Galili, E., Nir, Y., 1993. The submerged Pre-Pottery Neolithic water well of Atlit-Yam, northern Israel, and its palaeoenvironmental implications. The Holocene 3 (3), 265-270.

Galili, E., Weinstein-Evron, M., Hershkovitz, I., Gopher, A., Kislev, M., Lernau, O. Kolska-Horwitz, L., Lernau, H., 1993. Atlit-Yam: a prehistoric site on the sea floor off the Israeli coast. J. Field Archaeol. 20 (2), 133-157.

Galili, E., Rosen, B., Stern, E.J., Finkielsztejn, G., Kool, R., Bahat-Zilberstein, N., Sharvit, Y., Kahanov, Y., Friedman, Z., Zviely, D., 2007. New insights on maritime Akko revealed by underwater and coastal archaeological research. The Israeli Society for Aquatic Sciences, Forth Annual Meeting. Haifa University, pp. 64-74.

Galili, E., Rosen, B., Zviely, D., Silberstein, N., Finkielsztejn, G., 2010. The evolution of Akko harbour and its Mediterranean maritime trade links. J. Island Coast. Archaeol. 5 191-211.

Gambash, G., 2014. En route to Egypt: Akko in the Persian period. J. Near East. Stud. 73 (2), 273-282.

Haggi, A., Artzy, M., 2007. The harbour of Atlit in northern Canaanite/Phoenician context. Near East. Archaeol. 70 (2), 75-84.

Inbar, M., Sivan, D., 1984. Paleo-urban development and Late Quaternary environmental change in the Akko area. Paleorient 85-91.

Inman, D.L., Jenkins, S.A., 1984. The Nile littoral cell and man's impact on the coastal zone of the southeastern Mediterranean. Proc. 19th Conf. Coastal Engineering, Conf, Amer. Soc. Civil Engrs. Vol. 2, pp. 1600-1617

Kaniewski, D., Van Campo, E., Morhange, C., Guiot, J., Zviely, D., Shaked, I., Otto, T., Artzy, M., 2013. Early urban impact on Mediterranean coastal environments. Sci. Rep. 3, 3540.

Kaniewski, D., Van Campo, E., Morhange, C., Guiot, J., Zviely, D., Le Burel, S., Otto, T., Artzy, M., 2014. Vulnerability of Mediterranean ecosystems to long-term changes along the coast of Israel. PLoS One 9, 7.

Kingsley, S.A., Raveh, K. (Eds.), 1996. The ancient harbour and anchorage at Dor, Israel: results of the underwater surveys 1976-1991. British Archaeological Reports Vol. 626 (Oxford).

Lachenal, A.M., 1989. . Écologie des ostracodes du domaine méditerranéen : application au Golfe de Gabès (Tunisie orientale). Les variations du niveau marin depuis 30,000 ans. 1-238 (Documents des laboratoires de Géologie de Lyon).

Lena, A., 2012. Il porto di Magdala/Tarichea sul Lago di Galilea. PhD thesis in "Archeology: East-West Relations", Università di Napoli "L'Orientale", Napoli, (PhD in Italian, unpublished), 1-247.

Lichter, M., Zviely, D., Klein, M., 2009. Morphological changes in the last 200 years in the mouth of the Na'aman River, northern coastal plain, Israel. Israel J. Earth Sci. 58 (1), 63-80.

Lichter, M., Zviely, D., Klein, M., 2010. Morphological patterns of southeastern Mediterranean river mouths: the topographic setting of the beach as a forcing factor. Geomorphology $123,1-12$

Lichter, M., Klein, M., Zviely, D., 2011. Dynamic morphology of small south Eastern Mediterranean river mouths: a conceptual model. Earth Surf. Process. Landf. 36 547-562.

Marriner, N., 2009. Geoarchaeology of Lebanon's ancient harbours. Archaeopress, British Archaeological Reports, p. S1953 (Oxford).

Marriner, N., Morhange, C., 2007. Geoscience of ancient Mediterranean harbours. Earth-Sci. Rev. 80 (3), 137-194

Marriner, N., Morhange, C., Kaniewski, D., Carayon, N., 2014. Ancient harbour infrastructure in the Levant: tracking the birth and rise of new forms of anthropogenic pressure. Sci. Rep. 4, 5554.

Morhange, C., Marriner, N., 2011. Paleo-hazards in the coastal Mediterranean: a geoarchaeological approach. In: Martini, I.P., Chesworth, W. (Eds.), Landscapes and Societies, Selected Cases. Springer, pp. 223-234.

Morhange, C., Taha, M.H., Marriner, N., Humbert, J.B., 2005. Human settlement and coasta change in Gaza since the Bronze Age. Méditerranée 104 (1), 75-78.

Nir, Y., Eldar, I., 1987. Ancient wells and their geoarchaeological significance in detecting tectonics of the Israel Mediterranean coastline region. Geology 15 (1), 3-6.

Poppe, G., Goto, Y., 1991. European Seashells vol. I. Verlag Christa Hemmen, Weisbaden, pp. $1-352$.

Poppe, G., Goto, Y., 1993. European Seashells vol. II. ConchBooks, Hackenheim, pp. 1-221.

Porat, N., Sivan, D., Zviely, D., 2008. Late Holocene embayment infill and shoreline migration, Haifa Bay, eastern Mediterranean. Israel Journal of Earth Sciences 57, 21-31.

Raban, A., 1987a. Alternated river courses during the Bronze Age along the Israeli coastline. Déplacements des lignes de rivage en Méditerranée d'après les données de l'archéologie. CNRS, Paris.

Raban, A., 1987b. The harbour of the sea peoples at Dor. Biblic. Archaeol. 50 (2), 118-126.

Raban, A. (Ed.), 1988. Archaeology of coastal changes: proceedings of the first international symposium "Cities on the Sea-Past and Present", Haifa, Israel, September 22-29, 1986. British Archaeological Reports Vol. IS 404, pp. 1-252.
Raban, A., 1991. The port city of Akko in the MBII period. Michmanim 5, 17-34.

Raban, A., 1992. Sebastos: the royal harbour at Caesarea Maritima-a short-lived giant. Int. J. Naut. Archaeol. 21 (2), 111-124.

Raban, A., Hohlfelder, R.L., 1981. The ancient harbours of Caesarea Maritima. Archaeology 34 (2), 56-60.

Reimer, P.J., McCormac, F.G., 2002. Marine radiocarbon reservoir corrections for the Mediterranean and Aegean Seas. Radiocarbon 44, 159-166.

Reinhardt, E., Raban, A., 1994. Geoarchaeology of the ancient harbor site of Caesarea Maritima, Israel; evidence from sedimentology and paleoecology of benthic foraminifera. J. Foraminifer. Res. 24, 37-48.

Reinhardt, E.G., Raban, A., 1999. Destruction of Herod the Great's harbor Caesarea Maritima, Israel, geoarchaeological evidence. Geology 27, 811-814.

Reinhardt, E.G., Patterson, R.T., Schröder-Adams, C.J., 1994. Geoarchaeology of the ancient harbour site of Caesarea Maritima, Israel; evidence from sedimentology and paleoecology of benthic foraminifera. J. Foraminifer. Res. 24 (1), 37-48.

Reinhardt, E.G., Goodman, B.N., Boyce, J.I., Lopez, G., van Hengstum, P., Rink, W.J., Mart, Y., Raban, A., 2006. The tsunami of 13 December AD 115 and the destruction of Herod the Great's harbour at Caesarea Maritima, Israel. Geology 34 (12), 1061-1064.

Rosen, B., Galili, E., Zviely, D., 2012. The roman lighthouse in Akko, Israel. Int. J. Naut. Archaeol. 41 (1), 171-178.

Rossi, V., Sammartino, I., Amorosi, A., Sarti, G., De Luca, S., Lena, A., Morhange, C., 2014. New insights into the palaeoenvironmental evolution of Magdala ancient harbour (Sea of Galilee, Israel) from ostracod assemblages, geochemistry and sedimentology. J. Archaeol. Sci. 54, 356-373

Salmon, Y., 2014. A Second Millennium Geo-Archaeological and Palaeo-Environmental Study of the Nami Region: An Integrated Approach to a Coastal and Maritime Study. PhD thesis, University of Haifa, Haifa.

Sandler, A., Herut, B., 2000. Composition of clays along the continental shelf of Israel: contribution to the Nile versus local sources. Mar. Geol. 167, 339-354.

Sarti, G., Rossi, V., Amorosi, A., De Luca, S., Lena, A., Morhange, C., Ribolini, A., Sammartino, I., Bertoni, D., Zanchetta, G., 2013. Magdala harbour sedimentation (Sea of Galilee, Israel), from natural to anthropogenic control. Quat. Int. 303, 120-131.

Shtienberg, G., Zviely, D., Sivan, D., Lazar, M., 2014. Morphological coastal changes from seasonal to millennial scale: a case study from Caesarea, Israel. Geo-Mar. Lett. 34, 365-379.

Sivan, D., Gvirtzman, G., Sass, E., 1999. Quaternary stratigraphy and paleogeography of the Galilee coastal plain, Israel. Quat. Res. 51 (3), 280-294.

Sivan, D., Wdowinski, S., Lambeck, K., Galili, E., Raban, A., 2001. Holocene sea-level changes along the Mediterranean coast of Israel, based on archaeological observations and numerical model. Palaeogeogr. Palaeoclimatol. Palaeoecol. 167 (1), 101-117.

Sivan, D., Lambeck, K., Toueg, R., Raban, A., Porath, Y., Shirman, B., 2004. Ancient coastal wells of Caesarea Maritima, Israel, an indicator for relative sea level changes during the last 2000 years. Earth Planet. Sci. Lett. 222 (1), 315-330.

Sivan, D., Schattner, U., Morhange, C., Boaretto, E., 2010. What can a sessile mollusk tell about neotectonics? Earth Planet. Sci. Lett. 296 (3), 451-458.

Stanley, D.J., 2002. Early seafaring and maritime activity in the Southern Levant from Prehistory through the Third millennium BC. In: van den Brink, E.C.M, Levy Th, E. (Eds.), Egypt and the Levant, Interrelations from the 4th through the Early 3rd Millenium BCNew Approaches to Anthropological Archaeology. Leicester University Press, London, pp. 98-117.

Tepper, Y., 2010. A Pagan cemetery from the roman period at the foot of Tel Akko: evidence of the burial of roman soldiers and citizens of colonia Ptolemais. In: Killebrew, A.E., Raz-Romeo, V. (Eds.), One Thousand Night and Days, Akko through the Ages. Hecht Museum, University of Haifa, Haifa, pp. 33-39.

Toker, E., Sivan, D., Stern, E., Shirman, B., Tsimplis, M., Spada, G., 2012. Evidence for centennial scale sea level variability during the Medieval Climate Optimum (Crusader Period) in Israel, eastern Mediterranean. Earth Planet. Sci. Lett. 315, 51-61.

Vachtman, D., Sandler, A., Greenbaum, N., Herut, B., 2012. Dynamics of suspended sediment delivery to the Eastern Mediterranean continental shelf. Hydrol. Process. $27,1105-1116$

Wachsmann, S., Raveh, K., 1984. A Concise Nautical History of Dor Tantura. Int. J. Naut. Archaeol. 13, 223-241.

Wante, J., 2012. Géoarchéologie de Tel Akko (Israël). Master SET. Aix-Marseille University, pp. $1-31$.

Zviely, D., Sivan, D., Ecker, A., Bakler, N., Rohrlich, V., Galili, E., Boaretto, E., Klein, M., Kit, E., 2006. Holocene evolution of the Haifa Bay area, Israel, and its influence on ancient tell settlements. The Holocene 16 (6), 849-861.

Zviely, D., Kit, E., Klein, M., 2007. Longshore sand transport estimates along the Mediterranean coast of Israel in the Holocene. Mar. Geol. 237, 61-73.

Zviely, D., Kit, E., Rosen, B., Galili, E., Klein, M., 2009. Shoreline migration and beachnearshore sand balance over the last 200 years in Haifa Bay (SE Mediterranean). Geo-Mar. Lett. 29 (2), 93-110. 